\title{
WELFARE PROBLEMS IN DAIRY CALVES
}

\section{S. Hristov ${ }^{1}$, B. Stanković ${ }^{1}$, M. Todorović-Joksimović ${ }^{1}$, C. Mekić ${ }^{1}, Z$. Zlatanović $^{2}$, D. Ostojić-Andrićc ${ }^{3}$, N. Maksimović ${ }^{3}$}

${ }^{1}$ University of Belgrade, Faculty of Agriculture, 11080, Belgrade-Zemun, Republic of Serbia;

${ }^{2}$ College of agriculture and food technology, 27000 Prokuplje, Republic of Serbia;

${ }^{3}$ Institute for Animal Husbandry, 11080, Belgrade-Zemun, Republic of Serbia

Corresponding author: hristovs@agrif.bg.ac.rs

Original scientific paper

\begin{abstract}
The most significant welfare problems in dairy calves in intensive rearing conditions have been investigated in this paper. These problems mainly result from inadequate intake of colostrum (separation from the dam), inadequate ventilation (resulting in inappropriate airflow, low or high temperatures, high humidity and poor air quality), poor floor conditions (wet floor, without bedding), inadequate monitoring of health, exposure to pathogens causing respiratory and gastrointestinal disorders and occurrence of iron deficiency. In addition, on cattle farms in our country welfare problems in calves originate from continuous restocking (no "all in - all out") and mixing calves from different sources, as well as insufficiently balanced solid food, insufficient access to water and generally poor response of farmer to health problems, especially necessary dietary changes. A special welfare problem is insufficient floor space allowance which results in calf's discomfort.
\end{abstract}

Key words: calves, welfare, problems

\section{Introduction}

The organism of calves in the intensive rearing conditions is influenced by numerous unfavourable factors that may interfere fulfilling their basic needs. These factors may disturb normal breathing, feeding and watering, the development of the digestive tract, rest and sleep, behaviour, social contacts, thermoregulation and self-grooming of the calves. In addition, adverse factors can affect the appearance of fear, pain, injuries and diseases of calves.

Many complex factors contribute to the welfare of calves in commercial dairy farms, including housing and environment, nutrition programs, health, breeders, calves and procedures with dynamic changes in the size of the herd. Many data about these factors were presented in publications by Broom and Fraser (2007), Philips (2002), Rushen et al. (2008), Stull and Reynolds (2008). Provision and 
assessment of the welfare of calves in commercial dairy farms is a complex scientific challenge, especially because the terminology and assess factors that contribute to the welfare of calves are not clearly defined (Veissier, 1996; Vasseur et al., 2009; Vasseur et al., 2009a).

The aim of this paper is to assess the welfare indicators of calves on commercial dairy farms in our country and the basis for the consideration of the most common failures in maintaining the welfare of these categories of cattle.

\section{Materials and Methods}

The investigations on 18 composite indicators of calves' welfare on 15 commercial dairy farms were conducted. The sizes of the farms were from 50 to 600 cows, with the corresponding number of calves. Each indicator was tested including a detailed assessment of a number of parameters according to the methodology of Cziszter et al. (2009) i EFSA (2006) and rated using methodology of Hristov et al. (2010a). To asses welfare of calves at observed farms following scale of grades: (5 - excellent, 4 - very good, 3 - good, 2 - sufficient, 1 insufficient, with resources for improvement, and 0 - insufficient, with no resources for improvement) and rating scale (0-1,99 insufficient, 2,00-2,49 sufficient, 2,53,49 good, 3,5-4,49 very good and 4,5-5,00 excellent) were defined.

Assessment includes a written plan of welfare protection, management, competence of professionals and breeders, veterinary and zootechnical practices, maternal care, behavioural indicators (satisfaction of the behaviour system of calves, the ability to search and social contact), nutrition (colostrum, milk and solid foods), access to water, rearing conditions (space, microclimate and sanitary facilities; ventilation, flooring, light), health (respiratory and gastrointestinal disorders), physiological indicators (clinical values, iron deficiency), continuous use of facilities (without "all in-all out" system), mixing calves from different sources and production indicators of the welfare of calves.

\section{Results and Discussion}

The results of assessment of calves' welfare indicators on commercial cattle farms are shown in Table 1.

The research results, presented in Table 1, showed that there are no written plans for protecting the welfare of calves on the three observed farms. On other farms, these plans are present, but on the seven farms they are partial and unsystematic, and the remaining five farms they are mostly relevant. 
Table 1. Calves welfare indicators assessment

\begin{tabular}{|l|c|c|c|c|c|}
\hline Parameter & $0.00-1.99$ & $2.00-2.49$ & $2.50-3.49$ & $3.5-4.49$ & $4.5-5.00$ \\
\hline Written plans of welfare protection & 3 & 7 & 3 & 2 & 0 \\
\hline Management & 3 & 7 & 3 & 2 & 0 \\
\hline Competences of breeders & 0 & 1 & 11 & 3 & 0 \\
\hline Competences of professionals & 0 & 1 & 11 & 3 & 0 \\
\hline Veterinary and zootechnical practices & 0 & 1 & 11 & 3 & 0 \\
\hline Maternal care & 7 & 5 & 2 & 1 & 0 \\
\hline Behavioural indicators & 3 & 7 & 4 & 1 & 0 \\
\hline Nutrition & 3 & 5 & 6 & 1 & 0 \\
\hline Access to water & 2 & 2 & 10 & 1 & 0 \\
\hline Rearing conditions & 2 & 2 & 10 & 1 & 0 \\
\hline Ventilation & 2 & 2 & 10 & 1 & 0 \\
\hline Flooring & 2 & 2 & 10 & 1 & 0 \\
\hline Light & 2 & 2 & 10 & 1 & 0 \\
\hline Health & 3 & 6 & 4 & 2 & 0 \\
\hline Physiological indicators & 3 & 6 & 4 & 2 & 0 \\
\hline Continuous use of facilities & 2 & 5 & 4 & 2 & 2 \\
\hline Mixing calves from different sources & 1 & 1 & 1 & 10 & 2 \\
\hline Production indicators & 3 & 6 & 4 & 1 & 1 \\
\hline
\end{tabular}

Rating scale: 0-1.99 insufficient, 2.00-2.49 sufficient, 2.5-3.49 good, 3.5 - 4.49 very good and 4.5 -5.00 excellent.

When it comes to management on the welfare of calves, it was noted that there is unsystematic and fragmented experience of professionals on the ten farms. The management and governance was not adequate on three farms, and on the other seven farms could be described as satisfying, with numerous small failures. Competences of professionals and breeders (knowledge, skills and attitudes about the welfare of calves) on one farm have been assessed as sufficient, and on the remaining farms as good or very good. The study noted that professionals and breeders in general have a solid competence in terms of rearing conditions (space, microclimate and sanitary facilities, ventilation, flooring, lighting), food and watering, healthcare and the satisfaction of the basic behaviour of calves. Stockmen acquire their competence about welfare mainly on farms, without formal training; professionals learn in the respective institutions of higher education. Veterinary and zootechnical procedures related to the welfare of calves are mostly at the appropriate level on all farms, although certain failures were identified in this segment. Quality of space (floor features), microclimate (ventilation, microclimate factors) and the hygienic conditions of rearing (mechanical cleaning, sanitation) that affects the welfare of calves on farms was assessed as inadequate on two farms, sufficient for two and good on 10 farms. Behavioural indicators (satisfaction of all systems of animal behaviour, search and social contact), indicators of health status of calves (respiratory and gastrointestinal disorders), and food (quantity and 
quality of colostrum, milk and solid feed) and productivity (weight) are not at appropriate level on three farms.

On the farms where welfare of calves have been assessed as insufficient, omissions are mainly related to the separation of calves from the mother immediately after birth, insufficient quantity and quality of colostrum, inadequate ventilation (inadequate air flow, low or high temperatures, high humidity and poor air quality), bad floor characteristics (wet floor, floor without bedding), inadequate monitoring of the health of calves by breeders and poor hygienic conditions, leading to exposure of calves to respiratory and gastrointestinal disorders.

In addition, problems related to the welfare of calves originating from the continuous use of stable (non-existence system "all in - all out"), as well as underbalanced roughage to concentrate, lack of access to water and farmers generally untimely response to calf health problems, especially in necessary changes in the diet. A special problem of insufficient welfare of calves is surface of individual boxes that result in discomfort to the calves lying and standing.

An important indicator of welfare is the maternal care of calves (Broom and Fraser, 2007; Flower and Weary, 2003). It is known that the connection between the calf and its mother establishes by licking calves at birth. Licking calves stimulate activities which promote the search for tit (Fraser and Broom, 2007). Colostrum intake during the first six hours provides calves protection against infection and with very important nutrients. Good organization of after birth practice and supply calves with adequate amounts of quality colostrum is very important (EFSA, 2006; Hepola, 2008; Radostits et al., 2007). When feeding calves with milk, it is necessary to strictly take care of hygiene and milk temperature. Also, there is need to have in mind that the stomach of a newborn calf is small, so initially calves should be given small amounts of milk in several portions. In addition, immediately after birth, it is essential to do the best for hygiene of delivery space and equipment that is used to for the colostrum feeding which can significantly reduce the contact of calves with pathogenic organisms (EFSA, 2006; Hepola, 2003; Radostits et al., 2007).

The calves are separated from their mothers at an early stage and usually held individually in a small space in crates with preventing contacts with other animals (Flower and Weary, 2003). In the more spacious crates calves spend more time in self-grooming, while in constrained crates have difficulties in changing positions: lying and standing and limb extension during lying (Howard, 2003). Individual rearing disturbs development of social behaviour of calves. Young calves reared in group interact with each other more frequently than those kept individually (Hepola, 2003; Hepola, 2008). Long periods of social isolation lead to disruption of normal social behaviour in calves. Small crates reduce the expression of other behaviours, such as behaviour in the form of playing (Jensen et al., 1998). Spaces for calves must be so constructed that each calf could lie down and stand up, rest and self-groom without difficulty (DEFRA, 2003). 
Whether calves are kept in crates or in groups, nutrition has a major impact on the welfare state. The two most common problems are related to the low iron diet and lack of fibres. Food for calves must contain sufficient quantity of iron to provide the average level of haemoglobin in the blood of at least $4.5 \mathrm{mmol} / \mathrm{L}$, and minimum daily ration of roughage for each calf over two weeks in amounts that are increased from $50 \mathrm{~g}$ to $250 \mathrm{~g}$ per day for calves aged from eight to 20 weeks (DEFRA, 2003; Broom and Fraser, 2007; EFSA, 2006). All calves older than two weeks must have access to sufficient quantities of fresh water. In the case of high ambient temperature or in the case of the disease, calves must be always provided with fresh drinking water. Equipment for feeding and watering must be designed, constructed, installed and maintained in such a way that contamination of food and water is reduced to a minimum (DEFRA, 2003).

The owner or stuff responsible for animals must controlled calves facilities at least two times a day. For any calf showing signs of disease or injury, responsible person must immediately provide the appropriate care, and if the situation does not improve, have to ask the veterinarian for advice as soon as possible. If it is necessary, sick or injured calves have to be separated into appropriate areas with a dry and comfortable bedding (DEFRA, 2003; EFSA, 2006).

Floors have to be smooth but not slippery, preventing injuries of the calves, maiden and installed in away not to cause injury or suffering of standing or lying calves. Floors must match the size and body mass of calves and make a firm, flat and stable surface. Lying surface must be clean and comfortable, with adequate drainage and shall not negatively affect the calves. All calves under two weeks must be provided with adequate bedding. Calves must not be permanently kept in the dark. In order to meet the needs of calves with respect to behaviour and physiology, it must be ensured adequate natural or artificial lighting (DEFRA, 2003; EFSA, 2006).

In the first few days after the birth, some of the biggest problems concerning the welfare of calves are the digestive and respiratory diseases. Temperature and ventilation are closely related to the level of disease and thereby directly affect the welfare of calves. Provision of adequate food enables calves adaptation to a wide range of temperatures, with an upper critical temperature of $20-25^{\circ} \mathrm{C}$ and lower critical temperature of about $8^{\circ} \mathrm{C}$ at the age of one week (Webster, 1984).

\section{Conclusion}

According performed investigations of welfare of calves on commercial dairy farms could be concluded:

- on the most farms the separation of calves is carried out immediately after birth, which disrupts the establishment of social bonds between mother and calf, and negatively affect the welfare of calves; 
- significant failures in welfare protection plans, governance and management concerning the welfare, quality and quantity of colostrum, ventilation and characteristics of the floor were identified;

- weaknesses in monitoring the health of calves by the breeder, and creating unfavourable hygienic conditions leading to exposure of calves respiratory and gastrointestinal disturbances were identified;

- particular problem of the welfare of calves areas is inadequate size of individual crates, resulting in discomfort to the calves lying and standing.

\section{Acknowledgment}

The paper was financed by Ministry of Education and Science, Republic of Serbia, project TR31086.

\section{Problemi dobrobiti kod teladi}

S. Hristov, B. Stanković, M. Todorović-Joksimović, C. Mekić, Z. Zlatanović, D. Ostojić-Andrić, N. Maksimović

\section{Rezime}

$\mathrm{U}$ radu su istraženi najznačajniji problemi dobrobiti kod teladi $u$ intenzivnim uslovima gajenja. Ovi problemi su uglavnom posledica neadekvatnog uzimanja kolostruma (odvajanja od majke), neadekvatne ventilacije (dovodi do neodgovarajućeg protoka vazduha, niske ili visoke temperature, visoke vlažnosti i lošeg kvaliteta vazduha), loših uslova poda (vlažan pod, pod bez prostirke), neadekvatnog praćenja zdravlja teladi od strane odgajivača, izloženosti patogenim mikroorganizmima koji izazivaju respiratorne i gastrointestinalne poremećaje i pojave nedostatka gvožđa. Pored toga, na farmama u našoj zemlji problemi dobrobiti kod teladi potiču od kontinuiranog korišćenja staja (ne "sve unutra- sve napolje"), mešanja teladi iz različitih izvora, kao i od nedovoljno izbalansirane čvrste hrane, nedovoljnog pristupa vodi i generalno lošeg odgovora farmera na zdravstvene probleme teladi, a posebno neophodne promene u ishrani. Poseban problem dobrobiti teladi su nedovoljne površine individualnih boksova koje rezultiraju u neudobnosti teladi.

\section{References}

BROOM D., FRASER A. (2007): The welfare of cattle. In: BROOM D., FRASER A. (eds), Domestic animal behaviour and welfare, 4th ed., Cab International, 261. 
CZISZTER T.I., STANCIU G., ACATINCAI S., SZUCS E., ERINA SILVIA, TRIPON I., BAUL SIMONA (2009): Methods for calf welfare evaluation. Lucrări ştiințifice Zootehnie şi Biotehnologii, 42, 2.

DEFRA. (2003): Code of recommendations for the welfare of livestock. Cattle.

EFSA. (2006): The risks of poor welfare in intensive calf farming systems. An update of the Scientific Veterinary Committee Report on the Welfare of Calves. EFSA-Q-2005-014. European Food Safety Authority, Parma, Italy.

FLOWER F.C., WEARY D.M. (2003): The effects of early separation on the dairy cow and calf. Animal Welfare, 12, 339-348.

HEPOLA H. (2008): Rearing strategies of young dairy calves in relation to production, behaviour and welfare. $\mathrm{PhD}$. Thesis, Faculty of Agriculture and Forestry of the University of Helsinki, Finland.

HEPOLA H. (2003): Milk feeding systems for dairy calves in groups: effects on feed intake, growth and health. Applied Animal Behaviour Science, 80, 233-243.

HOWARD P. (2003): A review of calf health, welfare and rearing practices on UK dairy farms. Cattle Practice, 11, 173-180.

HRISTOV S., ZLATANOVIĆ Z., SKALICKI Z., STANKOVIĆ B. (2010): Procena dobrobiti krava primenom indeksa potreba životinja. Zbornik radova XV Savetovanje o biotehnologiji, Čačak, 15, 17, 473-478.

HRISTOV S., ZLATANOVIĆ Z., SKALICKI Z., STANKOVIĆ B., MAKSIMOVIĆ NEVENA (2010a): Procena dobrobiti krava na osnovu sistema ponašanja. Zbornik radova XXV Savetovanja agronoma, veterinara i tehnologa, 16, 3-4, 79-86.

JENSEN M.B., VESTERGAARD K.S., KROHN C.C. (1998): Play behaviour in dairy calves kept in pens: the effect of social contact and space allowance. Applied Animal Behaviour Science, 56, 97-108.

PHILLIPS CLIVE (2002): The welfare of calves. In Cattle behaviour and welfare, Blackwell Science Ltd, 30.

RADOSITIS O.M., GAY C.C., BLOOD D.C., CONSTABLE D.P. (2007): Veterinary Medicine. A textbook of the diseases of cattle, sheep, pigs, goats and horses. 10th ed. W.B. Saunders Company Ltd, London, UK.

RUSHEN J., DE PASSILLE A.M., VON KEYSERLINGK G.A.M., WEARY M.D. (2008): The welfare of cattle. Springer, Dordrecht, the Netherlands.

STULL C., REYNOLDS J. (2008): Calf Welfare. Veterinary Clinics of North America: Food Animal Practice, 24, 1, 191-203.

VASSEUR E., RUSHEN J., DE PASSILLE A.M., LEFEBVRE D. PELLERIN D. (2009): An advisory tool to improve management practices affecting calf and heifer welfare on dairy farms. J. Dairy Sci. TBC, 1-13.

VASSEUR E., RUSHEN J., DE PASSILLE A.M., LEFEBVRE D., FECTEAU G., PELLERIN D. (2009a): A diagnostic tool to assess calf welfare and management on-farm. J. Dairy Sci., 92, E-Suppl. 1, 501-502. 
VEISSIER I. (1996): Behavioural analyses in the studies on veal calves welfare. INRA Prod. Anim., 9, 2, 103-111.

WEBSTER A. J. F. (1984): Calf husbandry, health and welfare. Collins, London.

Received 30 June 2011; accepted for publication 15 August 2011 